\title{
O que diz a imprensa pernambucana a respeito do Programa Estadual de Mobilidade Urbana (PROMOB)?
}

\section{What does Pernambuco's press say about the State Program for Urban Mobility (PROMOB)?}

\author{
Alexandre Hochmann Béhar \\ Doutorando no Programa de Pós-Graduação em Administração da Universidade Federal de Pernambuco, Brasil, alexhb2@hotmail.com \\ http://lattes.cnpq.br/4988993702717451
}

André Luiz Maranhão de Souza Leão

Doutorado em Administração pela Universidade Federal de Pernambuco, Brasil, aleao21@hotmail.com http://lattes.cnpq.br/2313504052405431

Resumo: A mobilidade urbana se apresenta como um problema de grande impacto social e interesse político e econômico nas principais metrópoles brasileiras. Assim, destaca-se o papel do Estado na formulação e implementação de políticas públicas voltadas a estas questões, e da imprensa apresentando-se como um fiscal isenta e capacitada a avaliar as ações dos governantes. É neste cenário que tal estudo tem como objeto interpretar como se apresenta o discurso da imprensa pernambucana a respeito do principal programa de mobilidade urbana do governo do estado de Pernambuco, o PROMOB. Para realização deste estudo documental, portanto de cunho qualitativo, foram coletadas matérias jornalísticas dos dois jornais locais de maior circulação, e analisadas por meio da análise do discurso foucaultiana. Os resultados indicam que, maior que a preocupação em informar a sociedade e fiscalizar os governantes, o discurso da imprensa estaria direcionado em reforçar uma pretensa atuação objetiva e imparcial.

Palavras-chave: Análise do discurso foucaultiana, imprensa, políticas públicas, mobilidade urbana.

Abstract: Urban mobility is presented as a problem of great social impact and is also of political and economic interest in Brazil's major cities. Thus, we can highlight the state's role in the formulation and implementation of public policies related to these issues and also the press, appearing as a tax exempt and able to evaluate the actions of the rulers. Against this backdrop, this paper aims to interpret the presentation of the discourse of Pernambuco press regarding the main urban mobility program in the state of Pernambuco Government, the PROMOB. In order to perform this documentary study, thus, of qualitative nature, journalistic texts, of the two local newspapers with the largest circulation, were collected and analyzed through Foucault's discourse analysis. The results indicate that, greater than the concern to inform the company and supervise the rulers, the discourse of the press would be directed to strengthen an alleged objective and impartial performance

Key-words: Foucauldian discourse analysis, press, public policies, urban mobility

Texto completo em português: http://www.apgs.ufv.br Full text in Portuguese: http://www.apgs.ufv.br

\section{Introdução}

O histórico de manifestações recentes da sociedade brasileira ainda revela e destaca os eventos ocorridos a partir de junho de 2013. Inicialmente concentradas na cidade de São Paulo e lideradas por componentes do Movimento Passe Livre, as manifestações, que nos primeiros dias arregimentavam perto de quatro mil pessoas, em duas semanas tiveram seu número aumentado para aproximadamente 1,4 milhão de participantes, sendo realizadas em ao menos 120 cidades brasileiras (Peschansky, 2013). O contexto em que tais mobilizações se inserem, entretanto, parece não se limitar somente ao Brasil, sendo identificadas ações do mesmo tipo em países como Turquia, Irã, Egito e até mesmo nos Estados Unidos. Tais mobilizações, na opinião de Zizek (2013), simbolizariam reações ao processo de mundialização, capitaneado pelo viés econômico, fortemente associado à "expansão do reino do mercado, combinada ao enclausuramento do espaço público, à diminuição de serviços públicos (saúde, educação, cultura) e ao aumento do funcionamento autoritário do poder político" (Zizek, 2013, p.104).
Em tais circunstancias deve- se ainda destacar o caso brasileiro; fruto de um acelerado e concentrado processo de industrialização capitaneado e incentivado pelo Estado (Brito \& Souza, 2005). O processo de urbanização brasileiro se deu em velocidade muito superior ao acontecido nos países já industrializados (em período histórico equivalente frente ao início de sua industrialização) e, desta forma, além das dificuldades decorrentes da própria urbanização, outras questões mais complexas são acrescentadas (Brito, 2007). Assim, não surpreende que, no final do século $X X$, a percepção geral da população brasileira quanto à vida na maioria de suas cidades está associada à violência, formas diversas de poluição, alagamentos, bolsões de pobreza e trânsito congestionado (Maricato, 2003).

A problemática da mobilidade urbana nas metrópoles brasileiras parece se apresentar, portanto, como consequência direta da intensificação do modo de produção capitalista, através da expansão da industrialização. Sobre tal questão, deve-se destacar o papel do Estado brasileiro, não somente como principal vetor do processo de industrialização e consequente urbanização

Correspondência/Correspondence: Alexandre Hochmann Béhar,, Universidade Federal de Pernambuco. Tv. Prof. Morães Rêgo, 1235 - Cidade Universitária Recife - PE, 50670-901, Brasil alexhb2@hotmail.com 
brasileira, mas também como principal ator no planejamento, projeto e implementação das políticas públicas de mobilidade urbana no Brasil. Neste sentido, faz-se necessário observar-se também a influência exercida por interesses particulares, nacionais e estrangeiros, no desenvolvimento da infraestrutura de transportes brasileira (Nunes, 2011; Aragão et al., 2001).

Assim, destacam-se as relações clientelistas e patrimonialistas destas elites frente ao Estado brasileiro. Este movimento não se daria, entretanto, apenas em troca de verbas públicas e até mesmo relações ilícitas, mas também com a finalidade de atingir alto índice de popularidade para manutenção do poder. É por meio de tal manutenção que seria viabilizada a legalização e o direcionamento da ação e recurso público ao interesse privado (Ribeiro; Santos, 2007; Maricato, 2013).

Tal cenário, entretanto, possui mais um agente ativo, com papel altamente relevante e denominado muitas vezes como o "Quarto Poder" (em alusão aos outros três poderes constituintes do Estado democrático). Sobre tal aspecto, Souza (2006) e Kucinski (2011) se reportam ao poder das mídias. Esta não se apresentaria, entretanto, de maneira isolada ou independente de outras relações sociais.

Assim, ampliando a perspectiva para processos de comunicação, Martín-Barbero (2009) destaca o papel central destes na sociedade contemporânea, especificamente representada pelo reforço hegemônico da lógica do mercado sobre a sociedade. Este reforço relaciona-se ao aspecto produtivo maquinal dos bens simbólicos, adequados à determinada audiência. Ainda assim, as novas possibilidades decorrentes de tal mediação proporcionam, em si também, as oportunidades de transformação social, uma vez que "mais do que objetos de políticas, a comunicação e a cultura constituem hoje um campo primordial de batalha política" (Martín-Barbero, 2009, p.5).

Tal dimensão pode ser aproximada à perspectiva de Hall (2003), de que o processo de intermediação social assumido pela mídia não traria garantias quanto à compreensão de sua audiência. No entanto, isto não significa dizer que os processos comunicativos teriam seu poder diminuído, uma vez que sua veiculação possuiria forte tendência à orientação do posicionamento dos indivíduos receptores, ainda que se posicionem contrariamente ao que está sendo apresentado.

Entretanto, se ao menos nos principais países do mundo a mídia já é reconhecida como quarto poder, no Brasil tal questão parece ainda mais grave, considerando que "o mercado de mídia no Brasil é dominado por um punhado de magnatas e famílias" (BBC Brasil, 2011).

Especificamente, sobre a atuação da mídia/imprensa brasileira, destaca-se o profundo envolvimento com o poder político, considerando não somente o gigantesco gasto público com publicidade (Rodrigues, 2014), mas, especialmente, o fato de que diversos políticos são proprietários de veículos de mídia locais ou regionais (Stadnik, 1991; BBC Brasil, 2011). Desta forma, observa-se que os grandes veículos de mídia brasileiros se relacionam com atores inseridos nos grupos hegemônicos financeiros e políticos nacionais.

É neste contexto que o Governo do Estado de Pernambuco se insere como ator ativo na formulação e implementação de políticas públicas de mobilidade urbana. As principais ações de seus governantes, voltadas para tal questão, parecem concentradas na Região Metropolitana do Recife (RMR), através do Programa Estadual de Mobilidade Urbana, o PROMOB (Secretaria das Cidades, 2011), objeto deste estudo. Anunciado no segundo semestre de 2010, o PROMOB foi apresentado como um marco frente às políticas públicas de mobilidade urbana realizadas até então no estado (Governo do Estado de Pernambuco, s/d). Com investimentos de aproximadamente $\mathrm{R} \$ 2,5$ bilhões, os 10 projetos associados contam com recursos financeiros tanto da esfera federal, quanto da esfera estadual (PAC MOB) (Governo do Estado de Pernambuco, 2012). Identifica-se também, em determinados veículos da imprensa, tal expectativa e confiança quanto às melhorias advindas pela implementação de tal Programa, chegando a ser anunciado como o "trânsito do futuro no Recife" (jornal do Commércio, 2011).

Entretanto, analisando a perspectiva de desenvolvimento associada aos projetos do PROMOB, Béhar (2014), identificou que estes representariam mais a replicação das políticas públicas praticadas no passado do que propriamente um novo posicionamento dos governantes. Tal observação relaciona-se com características preponderantes das ações, como foco direcionado para projetos que beneficiem a utilização de automóveis, grandes construções, ações projetadas e iniciadas sem avaliação dos impactos ambientais, ou mesmo gerando impacto ambiental negativo, causando desalojamento de populações legalmente estabelecidas e beneficiando fortemente, e de diversas formas, o capital privado. Desta forma, propõe-se a seguinte questão de pesquisa: Como se apresenta o discurso da imprensa pernambucana em relação aos projetos associados ao PROMOB?

Tal estudo se justifica não somente pelo impacto socioeconômico das políticas públicas de mobilidade urbana e das já citadas influencias de grupos hegemônicos quanto à atuação do Estado brasileiro, mas também pelo relevante papel desempenhado pela imprensa na apresentação e divulgação das ações governamentais e do posicionamento dos demais atores da sociedade. Ressalta-se também a contribuição teórica deste estudo, no sentido de aplicação de uma ferramenta de análise sobre matérias jornalísticas, possibilitando contribuição metodológica de análise de dados a partir da análise do discurso foucaultiana.

Para tanto, nas sessões seguintes serão apresentados os conceitos teóricos e práticas metodológicas norteadores da pesquisa. Especialmente quanto à base teórica, serão tratados aspectos relacionados às políticas públicas de mobilidade urbana no Brasil e em Pernambuco (seção 2) e ao modelo codificação/decodificação de Hall (2003) (seção 3). Quanto às práticas metodológicas (seção 4), destaca-se a realização de uma análise do discurso foulcautiana, aderente a tradição pós- 
estruturalista sobre a qual se apoia este estudo. Desta forma foi realizada uma pesquisa qualitativa, através da prática de um estudo documental. Na seção 5 são apresentadas as descrições dos resultados e posteriormente as conclusões deste estudo.

\section{O Programa Estadual de Mobilidade Urbana (PROMOB)}

O PROMOB se insere no grupo de políticas públicas brasileiras relacionadas à mobilidade urbana. Assim, para melhor compreensão de seu processo constitutivo, observa-se a relevância em contextualizar historicamente as políticas públicas de mobilidade urbana no Brasil e na Região Metropolitana do Recife (RMR)

A partir da perspectiva nacional, observa-se que a elaboração e implantação das políticas públicas de mobilidade urbana relacionam-se fortemente a aspectos técnicos e econômicos, tendo em segundo plano as necessidades das sociedades envolvidas (Aração et al, 2001; Nunes, 2011). Tal cenário somente começa a ser alterado a partir da década de 1960 "quando vários dos seus pressupostos começaram a ser criticados e até contestados por propostas alternativas" (Vasconcellos, 2001, p.18).

Outros dois aspectos também se relacionam à formulação de políticas públicas de mobilidade urbana nacionais. Estes se apresentam tanto no aspecto de que "o desenvolvimento da infraestrutura implantada em toda a história dos transportes no Brasil esteve e está relacionado às estratégias dos grupos sociais e políticos hegemônicos" (Nunes, 2011, p.11), quanto com a perspectiva de que "a lógica do desenvolvimento desse tipo de infraestrutura não se entende apenas a partir dos acontecimentos no país, ele se insere, muito mais, em todo um processo internacional de mudanças econômicas, técnicas e políticas" (Aragão et al., 2001, p.95).

Assim, especificamente quanto às políticas públicas de transportes, há de se ressaltar a preponderante influência da indústria automobilística, especialmente a norte-americana, sobre as decisões do Estado na implementação da estrutura rodoviária no Brasil (Aragão et al., 2001; Maricato, 2008). Ainda nos dias de hoje a atuação do Estado brasileiro, nas suas mais diversas esferas, apresentar-se-ia caracterizada pelo mesmo clientelismo e assistencialismo do passado, mas nas últimas décadas, em troca de bons resultados nas eleições (Ribeiro; Santos, 2007). Sobre este aspecto, Maricato (2013, p.19) também observa que "há uma lógica entre legislação urbana, serviços públicos urbanos (terceirizados ou não), obras de infraestrutura e financiamento das campanhas eleitorais".

É neste contexto que se insere o Governo do Estado de Pernambuco, enquanto ator ativo na formulação e implantação de políticas públicas de mobilidade urbana. Entretanto, antes do detalhamento sobre O PROMOB, há de se ressaltar alguns aspectos sobre a região estudada (RMR), uma vez que esta se encontra entre as seis regiões metropolitanas brasileiras com mais de 3 milhões de habitantes e, além de sua relevância nacional, tal região apresenta vital importância para o estado. Constituída de 14 municípios, a região se apresenta concentrada em apenas $3 \%$ do território de Pernambuco, apresentando $42 \%$ da população e mais da metade do Produto Interno Bruto (PIB) estadual (Observatório das metrópoles, 2006).

Sobre tal região, ressalta-se que somente a partir da década de 1970, a RMR, assim como nos demais grandes centros urbanos brasileiros, direciona esforços em ações de planejamento urbano voltadas para o crescimento desta população. Este processo foi capitaneado pelo Grupo Executivo de Integração da Política de Transportes (GEIPOT) "com a finalidade de se definir um Sistema Metropolitano de Transporte Urbano de Passageiros e um Plano Diretor de Transporte" (Vainsencher, s/d). Destaca-se também, na década de 1970, em 1976, a criação do "Plano de Desenvolvimento Integrado da RMR" (Observatório das Metrópoles, 2006, p.95), aprovado pelo Conselho de Desenvolvimento da Região Metropolitana do Recife (CONDERM). Tal plano, ainda que pouco implementado (Passos, 2011), orientou a elaboração de outras ações setoriais do Estado, entre eles o Plano Diretor de Transportes (PDT), de 1982 e, no mesmo ano, o Plano de Desenvolvimento Metropolitano (PDM), (Observatório das Metrópoles, 2006).

A década de 1980 também é marcada por políticas públicas relacionadas à priorização do transporte coletivo. Neste sentido, cria-se a Empresa Metropolitana de Transportes Urbanos/ Recife (EMTU/Recife), com finalidade de ordenamento, monitoramento e controle do sistema de transporte coletivo por ônibus na RMR (Grande Recife Consórcio de Transportes, s/d).

É também na década de 1980 que se dá a constituição do Consórcio METROREC, a partir de decisão do Governo Federal por meio do Ministério dos Transportes. Tal consórcio foi constituído entre a Rede Ferroviária Federal S/A (RFFSA) e a Empresa Brasileira de Transportes Urbanos (EBTU), que deu início a construção do metrô em Recife, em janeiro de 1983 (Companhia Brasileira de Trens Urbanos - CBTU, s/d).

O que se identifica a partir de então são ações governamentais municipais desintegradas e independentes da gestão estadual, no que tange as políticas públicas de mobilidade urbana. Este cenário perdura até o lançamento do PROMOB, no segundo semestre de 2011. Seu anúncio foi associado ao objetivo principal de facilitar o trânsito de pessoas na RMR, de forma ambientalmente sustentável, e se utilizando dos meios de tecnologia da informação disponíveis (Prefeitura da Cidade do Recife, 2011). Desta forma, a fala dos governantes defende que as ações a ele associadas não resolverão somente os críticos problemas em relação à mobilidade urbana na RMR, especialmente através da priorização do transporte coletivo, mas também criarão novas opções de transporte para a região, lidando com o crescimento das cidades em seu entorno (Secretaria das Cidades, 2011).

Contudo, há de se ressaltar que tal programa não se apresenta de forma estática, sofrendo ajustes e alterações com o passar do tempo. Neste sentido já é possível observar relevantes alterações entre as duas versões apresentadas do Programa (Governo do Estado de Pernambuco, 2011; 2012). O Quadro 1 a 
seguir relaciona ambas as versões especificando os projetos e seus valores.

Quadro 1 - Lista de projetos do PROMOB por versão

\begin{tabular}{|c|c|c|}
\hline Projeto & PROMOB Original (2011) & PROMOB Ajustado (2012) \\
\hline Viadutos da Av. Agamenom Magalhães & $\begin{array}{c}\mathrm{R} \$ 180 \text { milhões } \\
\text { (não especificado) }\end{array}$ & Não previsto \\
\hline $\begin{array}{l}\text { Implantação de um corredor exclusivo de TRO na } \\
\text { Avenida Norte Miguel Arraes }\end{array}$ & $\begin{array}{l}\mathrm{R} \$ 200 \text { milhões } \\
\text { (não especificado) }\end{array}$ & Não previsto \\
\hline Implantação do Corredor Exclusivo da BR-101 & $\begin{array}{l}\mathrm{R} \$ 480 \text { milhões } \\
\text { (não especificado) }\end{array}$ & $\begin{array}{c}\text { Modificado para implantação de } \\
\text { TRO }\end{array}$ \\
\hline Implantação do Corredor de TRO da BR-101 & & $\begin{array}{l}\mathrm{R} \$ 774 \text { milhões } \\
\text { (DNIT/PAC MOB) }\end{array}$ \\
\hline Passarela do Aeroporto & $\begin{array}{l}\mathrm{R} \$ 22 \text { milhões } \\
\text { (não especificado) }\end{array}$ & $\begin{array}{l}\mathrm{R} \$ 23 \text { milhões } \\
\text { (Tesouro Estadual) }\end{array}$ \\
\hline Programa Rios da Gente - Navegabilidade & $\begin{array}{l}\mathrm{R} \$ 398 \text { milhões } \\
\text { (não especificado) }\end{array}$ & $\begin{array}{l}\mathrm{R} \$ 289 \text { milhões } \\
\text { (PAC MOB) }\end{array}$ \\
\hline Corredor Exclusivo de TRO Norte/Sul & $\begin{array}{l}\mathrm{R} \$ 159 \text { milhões } \\
\text { (PAC da Copa) }\end{array}$ & $\begin{array}{l}\mathrm{R} \$ 181 \text { milhões } \\
\text { (PAC da Copa) }\end{array}$ \\
\hline Corredor Exclusivo de TRO Leste/Oeste & $\begin{array}{l}\mathrm{R} \$ 165 \text { milhões } \\
\text { (PAC da Copa) }\end{array}$ & $\begin{array}{l}\mathrm{R} \$ 145 \text { milhões } \\
\text { (PAC da Copa) }\end{array}$ \\
\hline Ramal Cidade da Copa & $\begin{array}{l}\mathrm{R} \$ 132 \text { milhões } \\
\text { (PAC da Copa) }\end{array}$ & $\begin{array}{l}\mathrm{R} \$ 131 \text { milhões } \\
\text { (PAC da Copa) }\end{array}$ \\
\hline Terminal de Integração Cosme e Damião & $\begin{array}{l}\mathrm{R} \$ 17 \text { milhões } \\
\text { (PAC da Copa) }\end{array}$ & Não previsto \\
\hline II Perimetral e Via Metropolitana Norte & Não previsto & $\begin{array}{l}\text { R \$ } 266 \text { milhões } \\
\text { (PAC MOB) }\end{array}$ \\
\hline $\begin{array}{l}\text { Via Metropolitana Sul e contorno Lagoa Olho } \\
\text { D'Água }\end{array}$ & Não previsto & $\begin{array}{l}\mathrm{R} \$ 2,6 \text { milhões } \\
\text { (não especificado) }\end{array}$ \\
\hline Total & $\mathrm{R} \$ 1,753$ bilhão & $\mathrm{R} \$ 2,2$ bilhões \\
\hline
\end{tabular}

O décimo e último projeto a integrar o PROMOB, até o momento, foi o Programa PEDALA PE, criado em agosto de 2012, com investimentos de $\mathrm{R} \$ 22,4$ milhões. Tal programa tem como principal foco incentivar a utilização de bicicletas como meio de transporte e seu desenvolvimento se dá tanto através da construção de ciclovias (inseridas no projeto dos corredores exclusivos de ônibus), quanto por meio da instalação de bicicletários em diversos pontos da RMR, possibilitando, assim, a utilização do meio de transporte mesmo por quem não o possui (Governo do Estado de Pernambuco, 2012). Maiores detalhes sobre os programas são apresentados no Anexo II.

Desta forma, a partir das informações disponibilizadas, parece relevante dedicar-se às sessões seguintes, com aspectos teóricos e metodológicos que nortearão tal estudo. Portanto, a próxima sessão apresenta uma objetiva argumentação quanto a um modelo de compreensão sobre comunicações.

\section{Codificando e decodificando, uma forma de interpretar as comunicações}

Quanto ao entendimento sobre uma definição para o jornalismo, Souza (2006, p.193) observa que este, "na sua essência, corresponde, dominantemente à actividade profissional de divulgação mediada, periódica, organizada e hierarquizada de informações com interesse para o público". Sobre tal aspecto, apesar do aumento pela disputa pela atenção dos indivíduos, decorrente da popularização do acesso à internet e, com isso, maior volume de veiculadores de notícias, além das críticas endereçadas (especialmente) aos grandes veículos do jornalismo tradicional, identifica-se ainda que este se apresenta como poderosa ferramenta de divulgação e comunicação social, sendo ainda considerado um "Quarto Poder", ou mesmo "contra poder" (Souza, 2006, p.194).

Tais denominações, apoiadas na percepção democrática da liberdade de expressão, relacionam-se com o papel idealizado de que o jornalismo teria o papel de acompanhar e controlar ações dos demais poderes (Executivo, Legislativo e Judiciário), ressaltando-se, sobre tal aspecto, o fato de não se apresentar formalmente como um Poder (não apresenta suporte constitucional), necessitando, desta forma, exercício constante para sua legitimação junto à sociedade (Souza, 2006).

Diante de tais questões, há de se ressaltar o próprio conceito de mídia. Sobre este Guazina (2007) observa que não existe consenso quanto à definição de um conceito, entretanto observa que "seu uso predominante, pelo menos até 2004, parte de uma quase extensão ou decorrência natural de conjunto de meios de comunicação" (Guazina, 2007, p.51). Apesar da atual expansão do entendimento sobre mídia, identificado por Guazina (2007, p.55) "como um conceito ônibus que pode significar uma ampla gama de fenômenos, acontecimentos e transformações que envolvem a política, o jornalismo, a publicidade, o marketing, o entretenimento, nos diferentes meios", observa-se relevante que "a noção de media contém em si a noção de intermediário" (Souza, 2006, p.537), apresentando-se como um intermediário "entre um ou mais emissores e um ou mais receptores" (Souza,2006, p.537).

Neste sentido, quanto à relevância dos diversos meios de comunicação (rádio, televisão, imprensa, etc.), Souza (2006, p.539) observa que se "assenta, efectivamente, nessas enormes capacidades de representação das pessoas, da sociedade e da cultura; de produção e reprodução, de construção e reconstrução dos processos sociais e culturais".

Alinhado a tal questão, Ronsini (2010, p.2) compreende que "o estudo da mídia é também o estudo da reprodução cultural e social". Sobre tal aspecto, a autora destaca entre outras a obra de Martín-Barbero, identificando que para este o consumo do processo comunicacional apresentar-se-ia "determinado pela lógica política e econômica" (Ronsini, 2010, p.3), inseridas em contextos sócio-históricos. 
Ainda referenciando a obra de Martín-Barbero, Wottrich, Silva e Ronsini (2009, p.3) observam que, "entendendo a comunicação como práticas sociais, o autor utiliza o conceito de mediação como a categoria que liga a comunicação à cultura. As mediações são os lugares entre a produção e a recepção".

Questionando as limitações do modelo comunicacional tradicional, Martín-Barbero (2009, p.3) defende a perspectiva da "hegemonia comunicacional", que se apresenta na "comunicação convertida no mais eficaz motor de desengate e de inserção das culturas - étnicas, nacionais ou locais - no espaço/tempo do mercado e nas tecnologias globais". Apoiada sobre o conceito de mediação a partir das dimensões de sociabilidade, ritualidade e tecnicidade de Martín-Barbero, Wottrich, Silva e Ronsini (2009, p.4) destacam que "essa mediação diz respeito a toda vivência cultural que o indivíduo adquire ao longo da vida, não apenas através da educação formal, mas por meio das experiências adquiridas em seu cotidiano".

Entretanto, no que se relaciona à "batalha política" MartínBarbero et al (2009, p.4) destaca que:

o que estamos vivendo não é, como creem os mais pessimistas dos profetas-fim-de-milênio, a sua dissolução, senão a reconfiguração das mediações em que se constituem os novos modos de interpelação dos sujeitos e de representação dos vínculos que coesionam a sociedade. Mais que substituí-la, a mediação televisiva ou radiofônica passou a constituir, a fazer parte da trama dos discursos e da própria ação política.

Desta forma, observa-se que:

- modelo comunicacional barberiano estabelece a recepção midiática como um processo de interação, em que entre o emissor e o receptor há um espaço de natureza representativa ou simbólica que é preenchido pela mensagem, a qual é configurada com múltiplas variáveis. Essa complexidade de fatores que envolve a mensagem faz com que a intenção inicial emitida pelo emissor possa não vir ser a mesma captada e recebida pelo receptor (Dantas, 2008, p.2/3).

Também Hall (2003) apresenta uma crítica aos estudos clássicos da Comunicação, em decorrência da limitação ao esquema estático e linear emissor/mensagem/receptor, além de colocar sua ênfase sobre a troca de mensagens (Porto, 2003; Oliveira, 2009). Neste sentido o autor "propõe, então, analisar os processos comunicativos como processos produtivos, nos termos marxianos" (Oliveira, 2009, p.6), ou como observa Hall (2003, p.387) "pensar esse processo em termos de uma estrutura produzida e sustentada através da articulação de momentos distintos, mas interligados - produção, circulação, distribuição/consumo, reprodução".

Identificado como referência entre os estudos de comunicação, o modelo "está fundado na ideia de comunicação como estrutura sustentada por uma articulação entre momentos distintos - produção, circulação, distribuição, consumo" (Escosteguy, 2007, p.119), ainda que "igualmente necessários para que o circuito concretizasse" (Franco \& Leão, 2013, p.34). Sobre tal modelo, destaca-se que sua premissa é orientada para a percepção de que tanto nos momentos da produção da mensagem, quanto da recepção da mensagem, existem fatores histórico-sociais que influenciam o conteúdo das mesmas (Porto, 2003; Oliveira, 2009).

Sobre tal aspecto, baseados no modelo de Hall (2003), Franco e Leão (2013, p.38) destacam que "a codificação se constitui no momento da construção de um discurso significativo, por meio da organização de signos sobre regras e linguagem específicas". Tais ordenações apresentar-se-iam "permeadas pelas ideias e sentidos discursivos próprios daqueles ali envolvidos (...) levando em consideração também suposições sobre a audiência" (Oliveira, 2009 , p.6), ou como observa Hall (2003, p.389) "o processo de produção não é isento de seu aspecto 'discursivo': ele também se constitui dentro de um referencial de sentidos e ideias". Destacase também a observação de Escosteguy (2007, p.124) de que "embora o modelo proponha uma homologia com as estruturas da produção econômica dentro da sociedade capitalista (...) privilegia a forma textual do produto midiático, em detrimento da forma mercadoria". Neste sentido, Franco e Leão (2013, p.37/38), destacam como pressupostos do modelo, a partir de compreensão sobre Hall (2003) "uma nova visão do processo comunicativo, composto de momentos distintos, em articulação e sob condições de existência específica".

Em contrapartida, no processo de decodificação da mensagem, a "comunicação se realiza, onde a mensagem é consumida de forma ativa e não passiva" (Oliveira, 2009, p.6) ou, em outras palavras "a audiência pode decodificá-la com um significado diferente ou oposicional" (Porto, 2003). Sobre tal questão observa-se que o grau de simetria entre os códigos de codificação e decodificação pode não ser equivalente, gerando assim "'distorções ou 'mal-entendidos"' (Hall, 2003, p.319). Sobre tal aspecto, Escosteguy (2007, p.125) observa que "Hall assinala que as práticas de recepção não podem ser simplesmente vistas em termos comportamentais, mas são ordenadas por estruturas de compreensão, bem como produzidas por relações econômicas e sociais".

Destaca-se assim que "a proposta do autor tenta preservar a dinâmica do processo, desafiando a ideia da hierarquia entre produção e recepção, e de correspondência obrigatória entre elas" (Escosteguy, 2007, p.124). Entretanto, observa-se sobre o processo de codificação/decodificação, que o '“objeto' de tais práticas é composto por significados e mensagens sob a forma de signos-veículo de um tipo específico, organizados, como qualquer forma de comunicação ou linguagem pela operação de códigos dentro da corrente sintagmática de um discurso" (Hall, 2003, p.387). Desta forma, observa-se que "o 'conhecimento' discursivo é o produto não da transparente representação do 'real' na linguagem, mas da articulação da linguagem em condições e relações reais" (Hall, 2003, p.392).

A compreensão quando à mensagem, tanto ao codificador quanto ao decodificador, associa-se à compreensão de determinados códigos, que vem a ser "veículos simbólicos constituídos dentro das regaras de 'linguagem"' (Hall, 2003, p. 388). Sobre tal aspecto, ressalta-se que a mensagem só pode ser compreendida em determinado contexto histórico. Desta forma, "no momento em que um evento histórico é posto sob o signo do 
discurso, ele é sujeito a toda a complexidade de 'regras' formais pelas quais a linguagem significa" (Hall, 2003, p.388). Entretanto, faz-se relevante observar que "muito poucas vezes os signos organizados em um discurso significarão somente seus sentidos 'literais' (...). Em um discurso de fato emitido, a maioria dos signos combinará seus aspectos denotativos e conotativos" (Hall, 2003, p.395, grifo do autor). Em outras palavras, cabe destacar que "o autor não adere a uma posição determinista, mas também não exclui a presença de uma força dominante" (Escosteguy, 2007, p.126).

A partir de tal perspectiva, e apoiando sua análise a partir dos efeitos do discurso televisivo sobre sua audiência, Hall (2003) destaca sua interpretação sobre três possíveis articulações combinadas para codificação/decodificação: a hegemônica dominante, a do código negociado e a oposicionista. Entretanto, em qualquer uma destas condições, destaca-se que um determinado código dominante direciona o entendimento da audiência, seja completamente, parcialmente ou negando ele (Hall, 2003). Sobre tal aspecto, dois pontos devem ser ressaltados. O primeiro relaciona-se com a noção de que a orientação ideológica envolvida na construção da mensagem não se apresenta maior que o evento a ser comunicado em si, mas que ela se apresenta nos meandros de sua constituição, ou como observa Hall (2003, p.389)

naquele momento, as sub-regras formais do discurso estão 'em dominância', sem, é claro, subordinarem até seu apagamento o evento histórico que está sendo significado, as relações sociais nas quais as regras são postas em funcionamento ou as consequências políticas e sociais do evento terem sido significadas dessa maneira.

A segunda questão a ser ressaltada relaciona-se ao papel ativo do receptor na decodificação da mensagem. Sobre tal questão Hall (2003, p.399) observa que "é claro que sempre haverá leituras individuais, particulares ou variantes", entretanto, o direcionamento intencional e ideológico dado à mensagem (ou ao conjunto de códigos e signos que a compõe), tenderia a limitar as opções de interpretação e entendimento sobre o fato apresentado. Neste sentido Hall (2003, p.399) entende que "a 'percepção seletiva' quase nunca é tão seletiva, aleatória ou privatizada quanto o conceito sugere".

Conclusivamente, ressalta-se que

o processo comunicativo não consiste na atribuição nãoproblemática de cada item visual à sua posição dentro de um conjunto de códigos pré-arranjados, mas sim em regras performativas, ou sejam regras de competência e uso, de lógica aplicada - que buscam ativamente reforçar ou preferir um domínio semântico a outro e incluir e excluir itens dos conjuntos de sentido apropriados (Hall, 2003, p.397).

Sobre tal perspectiva, será dado prosseguimento ao detalhamento do estudo, por meio dos procedimentos metodológicos utilizados, que, neste caso, aproximam-se do entendimento de Hall (2003) sobre o processo de comunicação.

\section{Procedimentos metodológicos}

Conforme apresenta Flick (2009, p.21), "a mudança social acelerada e a consequente diversificação das esferas de vida fazem com que, cada vez mais, os pesquisadores sociais enfrentem novos contextos e perspectivas sociais". Assim entende-se que as questões locais ganham importância cada vez maior no espaço para a construção de conhecimentos diversos. Na pesquisa social, "as narrativas agora precisam ser limitadas em termos locais, temporais e situacionais" (Flick, 2009, p.21).

Sobre tais questões, destaca-se ainda a observação de Mariz et al. (2005, p.5), de que "sob o paradigma qualitativo, os estudos buscam entender problemas humanos ou sociais tendo como suporte um quadro complexo e holístico, formado propriamente com palavras que relatam a visão detalhada de informantes". Desta forma, considera-se que a utilização do paradigma qualitativo se apresenta mais adequado para realização da referida pesquisa.

Entretanto, antes de maior detalhamento quanto aos aspectos metodológicos deste estudo, destaca-se que estes estão associados a uma perspectiva crítica, vinculada à tradição pósestruturalista. A este respeito, observa-se que o pós-estruturalismo se apresenta como um movimento filosófico que busca determinados rompidos com a perspectiva estruturalista (Costa e Vergara, 2012).

A este respeito ressalta-se a observação de Paula (2008, p.24) de que os pós-estruturalistas "apresentam o sujeito descentrado e dependente do sistema linguístico, ou seja, um sujeito concebido em termos relacionais, constituído discursivamente, governado por estruturas e sistemas linguísticos [...]". Paula (2008, p.24) destaca ainda que o pós-estruturalismo "também enfatiza o inconsciente e as estruturas ou forças sócio históricas subjacentes que constrangem e governam o comportamento humano". Tais dimensões alinham-se a proposta analítica deste estudo: a análise do discurso foucaultiana, que será apresentada a seguir.

Antes de maior detalhamento quanto ao procedimento analítico, destaca-se que a constituição do corpus se deu através de matérias jornalísticas relacionadas à questão de pesquisa (os projetos associados ao Programa Estadual de Mobilidade Urbana PROMOB), coletadas em publicações on-line e portais de notícias da internet dos três jornais de maior circulação no estado de Pernambuco, a saber: Diário de Pernambuco (e o portal Pernambuco.com), Jornal do Commércio (e os portais NE10 e JC Online), além do portal FolhaPE. No total foram coletados 39 documentos relacionados à questão de pesquisa, concentrados no intervalo de tempo entre os anos de 2011 e 2014.

Quanto aos veículos analisados, destacam-se algumas informações. Inicialmente, quanto ao Jornal do Commércio, destaca-se que faz parte do Sistema Jornal do Commércio de Comunicação, que pertence ao Grupo JCPM, dirigido pelo empresário João Carlos Paes Mendonça e proprietário de shoppings centers, empreendimentos imobiliários, além do sistema de comunicação (Jornal do Commércio, s/d; JCPM, s/d). 
Líder há 21 anos no estado de Pernambuco, o jornal apresenta maior tiragem entre as publicações locais, atingindo mais de 44 mil exemplares nos dias úteis e quase 50 mil exemplares nos finais de semana. Além do jornal impresso, destaca-se que o portal JC online tem pico de 4,7 milhões de acessos por mês e 448 mil seguidores nas redes sociais (Jornal do Commércio, 2015).

O segundo jornal local com maior tiragem (média de 22.504 exemplares diários), de acordo com informações disponíveis no portal de internet, o Diário de Pernambuco foi fundado em 1825, sendo o jornal mais antigo em circulação na América Latina. Entretanto, desde 1931 o Diário de Pernambuco faz parte do grupo Diários Associados. Em 2008 o jornal contava com a estimativa de 390 mil leitores, sendo também a marca mais lembrada pelos recifenses segundo pesquisa da Associação Brasileira de Anunciantes (ABA) - Top Brands - Forças e Prestígio de Marcas 2007 (Diários Associados, s/d).

Em terceiro lugar destaca-se o portal de notícias FolhaPE. Associado ao jornal Folha de Pernambuco, pertencente ao Grupo EQM, que além do sistema de comunicação, possui atuação também nos ramos sucroalcoleiro e de energia. $O$ grupo não disponibiliza o número de acessos ao site ou tiragem do jornal impresso, entretanto, destaca o segundo lugar em leitores na RMR, em 2011 (FolhaPE; s/d).

Após o detalhamento quanto aos documentos que compõe 0 arquivo, seguir-se-á com o procedimento analítico. Sobre esta, observa-se que, como estratégia para a análise dos dados, optouse pela análise do discurso foucaultiana, apoiada no projeto arqueológico Foucault (2008). Tal decisão relaciona-se ao fato de que, na visão de Foucault (2008), é por meio do uso da linguagem, apropriada pelos sujeitos, que se estabelecem os conhecimentos considerados válidos por um determinado grupo ou sociedade, em específico período histórico.

Sobre os procedimentos analíticos, a partir dos discursos, destaca-se a afirmação de Foucault (2008, p.157) de que esta se debruça sobre os "próprios discursos, enquanto práticas que obedecem a regras, sem, contanto, apresentar-se como uma 'disciplina interpretativa'. Outro aspecto que caracteriza o método refere-se à intenção de "mostrar em que sentido o jogo das regras que utilizam é irredutível a qualquer outro; segui-los ao longo de suas arestas exteriores para melhor salientá-los" (Foucault, 2008, p.157). A respeito do uso da linguagem Foucault (2012, p.8) observa que

suponho que em toda sociedade a produção do discurso é ao mesmo tempo controlada, selecionada, organizada e redistribuída por certo número de procedimentos que têm por função conjurar seus poderes e perigos, dominar seu acontecimento aleatório, esquivar sua pesada e temível materialidade.

Neste sentido, "essa descrição se distingue facilmente da análise da língua" (Foucault, 2008, p.30), pois, o campo onde interagem os elementos discursivos, "é o conjunto sempre finito e efetivamente limitado das únicas sequências linguísticas que tenham sido formuladas" (Foucault, 2008, p.30). Assim, a análise dos recortes realizados se deu por meio da interpretação do interior do campo discursivo, através da definição de suas unidades e da descrição de suas relações ou, como observa o autor:

trata-se de compreender o enunciado na estreiteza e singularidade de sua situação; de determinar as condições de sua existência, de fixar seus limites da forma mais justa, de estabelecer suas correlações com os outros enunciados a que pode estar ligado, de mostrar que outras formas de enunciação exclui (Foucault, 2008, p.31).

O início do processo de análise se deu através da identificação dos enunciados. Quanto a estes, observa-se que se apresentam como um determinado conjunto ou agrupamento de signos que proporcionam a constituição de algum saber. Neste sentido Foucault (2008, p.110) observa que:

um enunciado tem sempre margens povoadas de outros enunciados. Essas margens se distinguem do que se entende geralmente por 'contexto' - real ou verbal -, isto é do conjunto dos elementos de situação ou de linguagem que motivam uma formulação e lhe determinam o sentido.

Desta forma, apresenta-se possível a realização do segundo passo: revelar as funções relativas aos enunciados, as chamadas funções enunciativas. Este conceito relaciona-se a noção de que o enunciado "é dotado de uma certa lentidão modificável, de um peso relativo ao campo que está colocado, de uma constância que permite utilizações diversas, de uma permanência temporal, e que não dorme sobre o próprio passado"

O terceiro passo constitui-se na identificação das "regras de formação" (Foucault, 2008, p.43), que vem a ser o sentido relativo às estruturas discursivas associadas à prática de uma determinada sociedade, ou como especifica o autor "as condições a que estão submetidos os elementos dessa repartição (objetos, modalidade de enunciação, conceitos, escolhas temáticas)" (Foucault, 2008, p.43).

A partir das relações estabelecidas entre os enunciados, as funções enunciativas e as regras de formação, espera-se ser possível revelar as formações discursivas presentes no campo discursivo. Como observa o autor:

no caso em que se puder descrever, entre um certo número de enunciados, semelhante sistema de dispersão, e no caso em que entre os objetos, os tipos de enunciação, os conceitos, as escolhas temáticas, se puder definir uma regularidade (uma ordem, correlações, posições e funcionamentos, transformações), diremos, por convenção, que se trata de uma formação discursiva (Foucault, 2008, p.43)

Em relação aos critérios de validade e confiabilidade ressaltase, a partir do que observam Paiva, Leão e Mello (2011), foco especial na construção do corpus de pesquisa (equivalente ao arquivo de Foulcaut). Sobre este, destaca-se que não é por meio da quantidade de documentos analisados que se demonstra a relevância do corpus, buscando efetivamente uma espécie de saturação na análise (Paiva, Leão \& Mello, 2011). Neste sentido, destaca-se que foram selecionados artigos jornalísticos dos dois principais jornais do estado, contemplando todos os projetos associados ao PROMOB, inclusive em diferentes momentos de sua realização.

A partir de apurada seleção de documentos para construção do corpus, outro critério de validade e confiabilidade destacado refere-se à "descrição clara, rica e detalhada" (Paiva, Leão \& 
Mello, 2011, p.201), neste caso, em relação aos documentos selecionados para a análise. Neste sentido observa-se a utilização de trechos dos documentos no decorrer da análise, bem como a disponibilização das matérias utilizadas para pesquisa ao final do estudo (anexo A), possibilitando acompanhamento e repetição do caminho analítico realizado nesta pesquisa. Há de se considerar, entretanto, o próprio caráter interpretativo da pesquisa qualitativa, o que leva ao entendimento de que a subjetividade do pesquisador estará presente no desenvolvimento da pesquisa (Paiva, Leão \& Mello, 2011). A partir dos conceitos apresentados, no próximo tópico serão detalhados os achados presentes nos dados analisados.

\section{Descrição dos resultados}

A respeito do modelo teórico de Hall (2003) apresentado na seção 3, cabe observar que as análises aqui apresentadas não se relacionam completamente com o mesmo, uma vez que não aprofundam os momentos de produção, consumo e reprodução. Entretanto, destaca-se em relação ao modelo codificação/decodificação, que a análise estaria concentrada no momento de circulação da comunicação, tendo este como base para interpretação quanto à intencionalidade da lógica produtiva da mensagem jornalística. Este aspecto interpretativo a partir do discurso apresentado alinha-se à utilização da análise do discurso foucaultiana, proposta analítica já apresentada.

O momento de circulação relaciona-se, neste estudo, a notícia em si, veiculada por meio de jornais impressos e portais na internet. Tal circulação apresenta peculiaridades específicas, uma vez que coloca o agente produtor da comunicação em situação de destaque, já que este se apresenta como um ator social, mediador da ação social. Neste sentido, a partir de Hall (2003), o momento de produção da comunicação tende a estar associado a processos ideológicos, na reafirmação dos interesses de grupos hegemônicos. Compreende-se, desta forma, que o discurso apresentado por este ator pode revelar determinada intencionalidade na produção comunicativa.

Sobre tal proposta, ressaltar-se a observação de Foucault (2008, p.98), de que:

o enunciado (...) é uma função da existência que pertence, exclusivamente, aos signos, e a partir da qual se pode decidir, em seguida, pela análise ou pela intuição, se eles 'fazem sentido' ou não, segundo que regra se sucedem ou se justapõem, de que são signos, e que espécie de ato se encontra realizado por sua formulação.

Neste sentido, observa-se que o enunciado "não é em si mesmo uma unidade, mas sim uma função que cruza um domínio de estruturas e de unidades possíveis e que faz com que apareçam, com conteúdos concretos, no tempo e no espaço" (Foucault, 2008, p.98). Desta forma, apresenta-se abaixo a relação de enunciados identificados na análise dos documentos.

\subsection{Relação de enunciados}

5.1.1. As ações do PROMOB propiciarão melhores condições de vida para a população.
Tal enunciado está relacionado à percepção de que a comunicação é realizada no sentido de que o projeto propiciará melhores condições de transporte, locomoção e, consequentemente, de qualidade de vida para os moradores ou visitantes da região onde o mesmo será realizado. Como exemplos são destacados os trechos a seguir:

a. "nova via será a redenção de Olinda e Paulista, no Grande Recife"

b. "o BRT apresenta uma estrutura mais confortável que os ônibus tradicionais"

5.1.2. As ações do PROMOB realizarão grande investimento de dinheiro público em diversos projetos.

Quanto a este enunciado relaciona-se a perspectiva de que os projetos são grandiosos, em estrutura, importância e valores, por isso precisam ter suas características e benefícios detalhados para a população. A seguir são apresentados exemplos do enunciado:

c. "toda a via está orçada em $\mathrm{R} \$ 400$ milhões recursos do PAC de Mobilidade"

d. "Estado garante R\$1,7 bilhão do PAC2"

5.1.3. Somente os atuais governantes apresentam real interesse em concretizar a realização das ações do PROMOB, mesmo aquelas previstas há muitos anos.

É identificado na comunicação presente nos documentos que determinados projetos já haviam sido apresentados por governantes e técnicos, no passado. Entretanto, ainda que não sejam detalhados os motivos, estes nunca foram ao menos iniciados. Tal descrição enunciativa relaciona, portanto, à dimensão de que os atuais governantes apresentaram real propensão em levar a cabo seus planos, apresentando inclusive, tais projetos em detalhes, com os devidos orçamentos e fonte de recursos (algo até então nunca realizado). Como exemplos para tal enunciado, apresenta-se:

e. "a obra surge como uma intervenção histórica"

f. "Idealizada e pelo menos 30 anos. A via metropolitana norte começa a sair do papel"

g. "o projeto é antigo, mas agora está pegando carona nos investimentos que vêm sendo feitos em mobilidade"

5.1.4. Apesar das promessas dos atuais governantes, existem dúvidas sobre a real implementação dos projetos do PROMOB.

Ainda que tenham sido identificadas as expectativas pelo atendimento de demandas e expectativas anteriores, quanto à execução dos planos de mobilidade, observa-se certa cautela diante das promessas dos atuais governantes, uma vez que estas também não teriam sido cumpridas pelos governantes passados. Como exemplo deste enunciado, destacam-se:

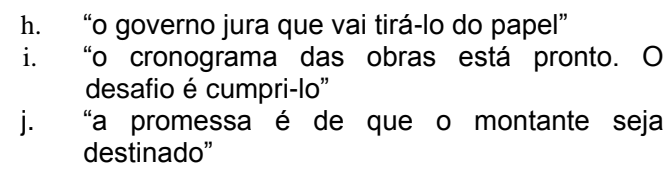

5.1.5. As ações do PROMOB propagam investimento público em transporte coletivo e alternativo.

Sobre este enunciado observa-se, em diversas partes dos textos analisados, o destaque aos investimentos ou mesmo a priorização do transporte coletivo ou alternativo (este 
especialmente relacionado ao Programa Pedala PE). Quanto ao enunciado, são destacados os seguintes exemplos:

k. "a região metropolitana ganhará cerca de 100 km de ciclovias"

I. "o projeto do governo prevê corredores exclusivos de ônibus"

5.1.6. A execução ineficiente dos projetos do PROMOB, pelo governo, incorre em perda e risco para uma parcela da população.

Apesar de todo o planejamento apresentado pelo governo, a execução dos projetos apresenta riscos à vida, saúde ou mesmo aos recursos da população, através do atraso no pagamento das desapropriações ou da implantação dos projetos sem prévia preocupação com aspectos de segurança, especialmente do pedestre. Quanto a este enunciado, destacam-se os seguintes exemplos:

m. "obras de mobilidade do recife deixam o pedestre na rua"

n. "destaca a diminuição da área verde do Recife, sem consulta à população"

5.1.7. O excesso de burocracia atrapalha a execução dos projetos planejados.

Tal enunciado relaciona-se à percepção de que os projetos associados ao $\mathrm{PROMOB}$, tão desejados e necessários à população, têm dificultada sua implementação em decorrência do excesso de burocracia, até mesmo no sentido de inviabilizar o planejamento governamental. Quanto a este enunciado, destacase o exemplo a seguir:

o. "sem estudos de impacto ambiental, projeto de navegabilidade do Rio Capibaribe enfrenta primeiro obstáculo"

\subsubsection{A ineficiência atrapalha a execução dos projetos planejados.}

A descrição deste enunciado relaciona-se à identificação de que, ainda que os projetos associados ao PROMOB sejam desejados e necessários à população, a falta de competência dos executores do Estado inviabiliza ou retarda sua implementação. Este enunciado relaciona-se a interpretação de trechos como o abaixo: p. "começaram os imprevistos no corredor leste-
oeste"

5.1.9. A intromissão de outros órgãos do Estado atrapalha a execução dos projetos planejados.

Este anunciado também se relaciona às ações que inviabilizem ou interrompam os projetos associados ao PROMOB, mais uma vez sendo destacado o desejo e necessidade da população quanto a eles. Desta vez, entretanto, é o envolvimento de outros órgãos do próprio Estado que inviabiliza ou retarda a implementação dos projetos. Quanto a este enunciado, é identificado o trecho abaixo:

q. 'Belize 'recomenda', ainda, à Secretaria das Cidades e à Empresa Metropolitana de Engenharia, (...), que não iniciem qualquer intervenção no Rio Capibaribe"
Desta forma, a partir da identificação das descrições enunciativas, buscou-se aprofundamento da análise para destacamento das funções associadas às tais práticas enunciativas, considerando o contexto determinado. Estas são apresentadas no sub-tópico seguinte.

5.2 - Funções enunciativas

5.2.1. - Concordar com os projetos propostos pelos governantes.

A descrição associada a tal função enunciativa relaciona-se à dimensão de aceitar como corretas as medidas tomadas pelos governantes, em relação aos projetos de mobilidade urbana na RMR. Como exemplo para tal função, apresenta-se o trecho abaixo:

a. "representará uma importante solução viária para as cidades de Olinda e Paulista"

\subsection{2. - Legitimar as decisões tomadas pelos governantes.}

O entendimento sobre esta função enunciativa relaciona-se com a ação de defender as decisões tomadas pelos governantes, e consequentemente dos projetos de mobilidade urbana previstos. O trecho abaixo representa um exemplo sobre tal função:

b. "de acordo com $65 \%$ dos entrevistados, os problemas relacionados à mobilidade urbana são os que causam maior impacto na vida da população"

5.2.3. - Questionar a real possibilidade de implementação dos projetos.

Esta função enunciativa relaciona-se com a ação de indagar a real capacidade ou interesse dos governantes em levar a cabo os projetos planejados. Como exemplo, são destacados os trechos abaixo:

c. "o cronograma das obras está pronto. O desafio é cumpri-lo"

d. "o governo jura que vai tirá-lo do papel"

5.2.4. - Denunciar os erros relacionados à implantação dos projetos.

Tal função enunciativa relaciona-se à noção de divulgação das ações identificadas como indevidas na realização das ações pelos representantes do poder público, ou empresas por eles contratadas. A seguir segue exemplo de trecho que representa tal função enunciativa:

e. "obras de mobilidade do recife deixam o pedestre na rua"

5.2.5 - Desaprovar ações que retardem ou impossibilitem a implantação dos projetos.

Por fim, esta função enunciativa relaciona-se a ação de condenar ações de terceiros que impactem o andamento natural dos projetos, conforme previsão inicial dos governantes. $O$ trecho a seguir exemplifica tal função.

f. "a história se repete. Mais um projeto do governo de Pernambuco começa a enfrentar obstáculos por não ter estudos de impacto recomendados pela legislação brasileira". 


\subsection{Regras de Formação}

A partir da identificação dos enunciados e das funções a eles associadas, torna-se possível revelar as práticas sociais, ou "condição de existência" (Foucault, 2008, p.43), de um determinado campo discursivo, ou seja, as regras discursivas. Estas encontram-se relacionadas e descritas no Quadro 7.

Quadro 7 - Regras de formação

\begin{tabular}{|l|l|l|}
\hline \multicolumn{1}{|c|}{ Regra } & \multicolumn{4}{|c|}{ Descrição } \\
\hline $\begin{array}{l}\text { Favorável às } \\
\text { propostas dos } \\
\text { governantes. }\end{array}$ & $\begin{array}{l}\text { Posição favorável às propostas } \\
\text { apresentadas pelos governantes, } \\
\text { associando a estes benefícios que serão } \\
\text { proporcionados a maior parte da } \\
\text { sociedade. }\end{array}$ \\
\hline $\begin{array}{l}\text { Papel de fiscal } \\
\text { dos } \\
\text { governantes. }\end{array}$ & $\begin{array}{l}\text { Evidenciar conduta investigativa na } \\
\text { execução dos projetos, revelando } \\
\text { ineficiências, erros ou riscos a sociedade, a } \\
\text { partir daquilo que foi proposto pelos } \\
\text { governantes. }\end{array}$ \\
\hline
\end{tabular}

Fonte: Elaborado pelos autores, 2015.

A seguir serão apresentados detalhes da constituição das regras, a partir dos enunciados e funções enunciativas, destacando tal conexão e apresentando exemplos.

\subsubsection{Favorável às propostas dos governantes}

A compreensão de tal regra relaciona-se a apresentação de argumentos que, de alguma maneira, se apresentem favoráveis aos projetos e ações vinculadas ao PROMOB. Em outras palavras, tal regra representa a crença nas decisões tomadas pelos governantes, ao menos no que se refere a projetos de mobilidade urbana. É neste sentido que esta regra se constitui das funções enunciativas: Concordar com os projetos propostos pelos governantes, legitimar as decisões tomadas pelos governantes e desaprovar ações que retardem ou impossibilitem a implantação dos projetos.

Por consequência, e mantendo a mesma conceituação a respeito da regra, vinculam-se a esta os seguintes enunciados: As ações do PROMOB propiciarão melhores condições de vida para a população, as ações do $\mathrm{PROMOB}$ realizarão grande investimento de dinheiro público em diversos projetos, somente os atuais governantes apresentam real interesse em concretizar as ações do PROMOB, mesmo aquelas previstas há muitos anos, as ações do PROMOB propagam investimento público, outros meios de transporte, diferentes do automóvel. O excesso de burocracia atrapalha a execução dos projetos planejados, a intromissão de outros órgãos do Estado atrapalha a execução dos projetos planejados, apesar das promessas dos atuais governantes, existem dúvidas sobre a real implementação dos projetos do PROMOB.

Apresenta-se como um exemplo desta regra o seguinte recorte: Na justificativa da "recomendação", a promotora de Justiça Belize Câmara lembra que uma mera autorização não substitui os estudos ambientais, exigidos por lei e por resoluções do Conselho Nacional do Meio Ambiente (Conama). E vai mais além: diz para a CPRH não tentar emitir nova autorização e que, antes de mais nada, o órgão deve promover uma audiência pública exclusivamente para tratar da dragagem. Caso contrário, todo o projeto pode ficar inviabilizado.

Desta forma, parece relevante apresentar a representação gráfica das relações associadas à referida regra, apresentada pela figura 1 a seguir:

Figura 1 - Relações vinculadas a Regra "Favorável aos projetos"

Enunciados

Funções Enunciativas

Regras

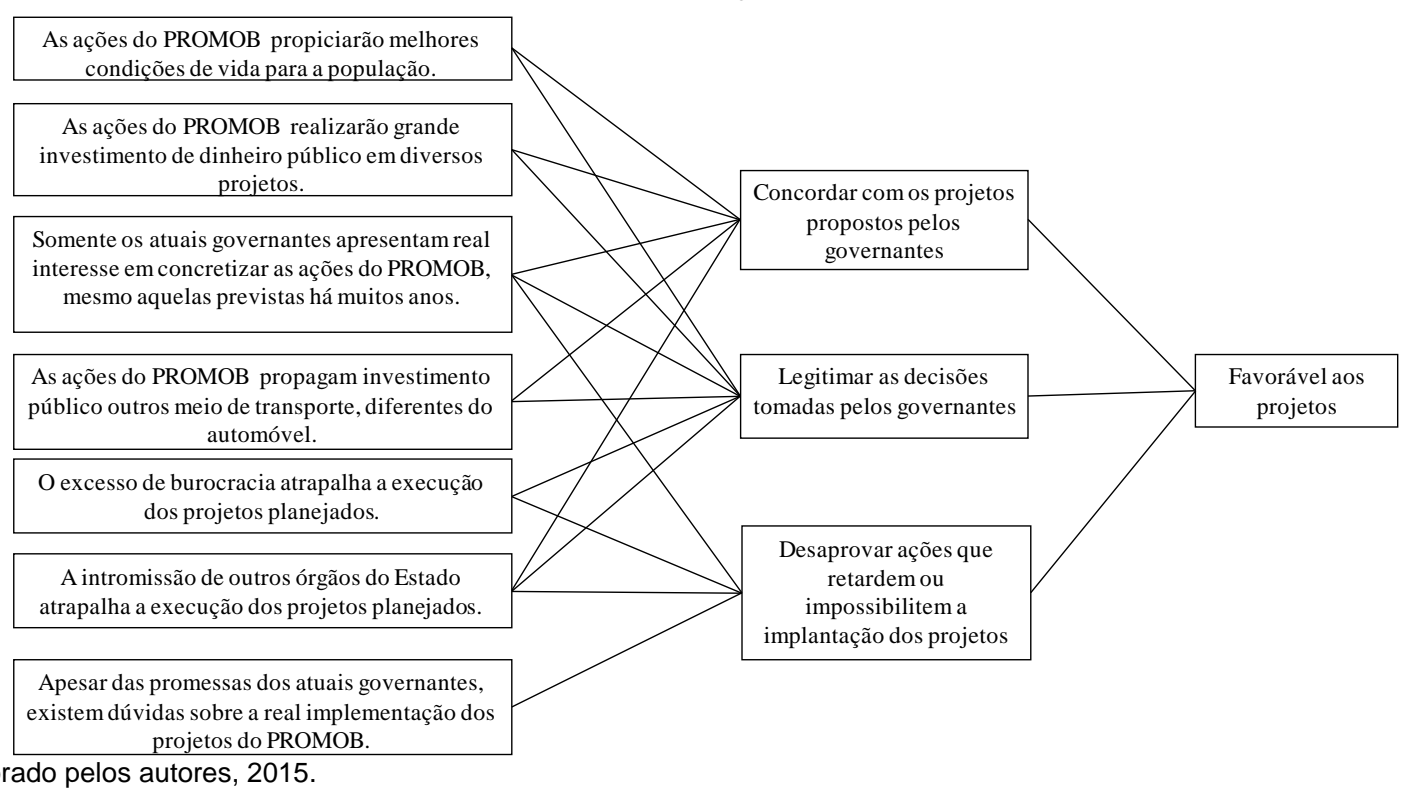

Fonte: Elaborado pelos autores, 2015.

\subsubsection{Atua como fiscal dos governantes}

A referida regra relaciona-se a compreensão de que não se pode ter total confiança de que a execução dos projetos de mobilidade urbana associados ao PROMOB será feita de forma eficiente e dentro do planejamento previsto, ou até mesmo se será implementada. É válido observar, entretanto, que tal regra não 
apresenta questionamento ou crítica aos projetos, parecendo relacionar-se com os mesmos de forma positiva. Sua orientação, ao contrário, aponta para dúvidas quanto a real implementação dos projetos ou mesmo por meio de críticas à execução ineficiente por parte dos governantes ou ainda das barreiras impostas pelo que é apresentado como excesso de burocracia ou intromissão de outros órgãos do Estado.

A partir desta definição, pode-se inferir que tal regra se constitui da relação das funções enunciativas desaprovar ações que retardem ou impossibilitem a implantação dos projetos, questionar a real possibilidade de implementação dos projetos, denunciar os erros relacionados à implantação dos projetos, e, desta forma, relacionam-se aos enunciados. Somente os atuais governantes apresentam real interesse em concretizar as ações do PROMOB, mesmo aquelas previstas há muitos anos, o excesso de burocracia atrapalha a execução dos projetos planejados, a intromissão de outros órgãos do Estado atrapalha a execução dos projetos planejados, a ineficiência atrapalha a execução dos projetos planejados, apesar das promessas dos atuais governantes, existem dúvidas sobre a real implementação dos projetos do $\mathrm{PROMOB}$, a segurança e o cuidado à população não é prioridade na execução dos projetos do PROMOB.

Como exemplo da referida regra apresentam-se o seguinte recorte: O secretário-executivo de Mobilidade Urbana de Pernambuco, Gustavo Gurgel, afirmou ontem que o Ramal Cidade da Copa só deve ficar pronto em maio, um mês antes do início do torneio. No mês passado, durante a visita do ministro das Cidades, Aguinaldo Ribeiro, secretários de três pastas do governo estadual haviam garantido que as obras seriam concluídas até março. A demora nas desapropriações e a chuva fora de época foram os motivos alegados para postergação do prazo.

A representação gráfica das relações é apresentada pela figura 2, a seguir:

Figura 2 - Relações vinculadas a regra "Atua como fiscal dos governantes"

\section{Enunciados}

\section{Funções Enunciativas}

Regras

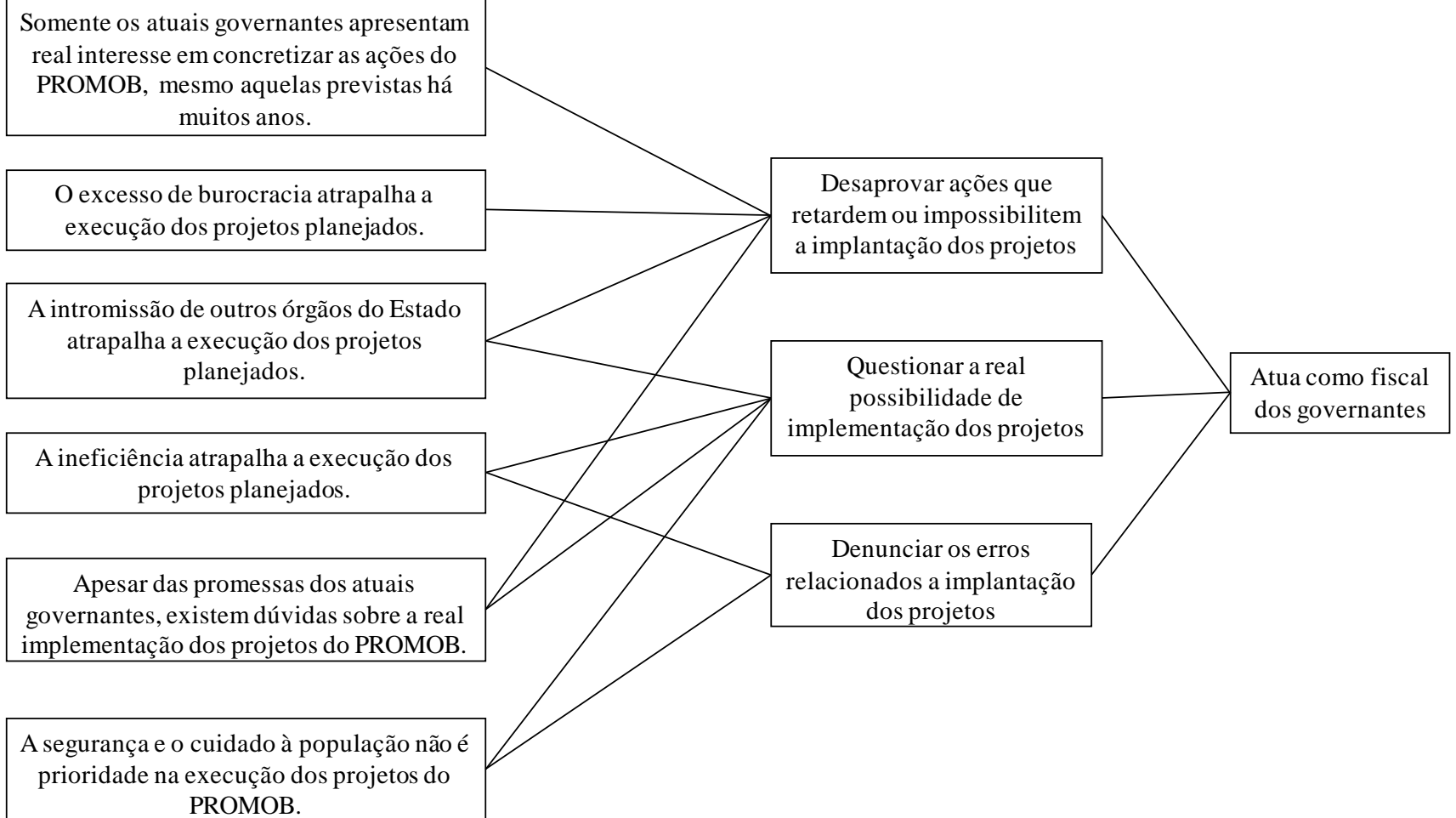

Fonte: Elaborado pelos autores, 2015

\subsection{Formação discursiva}

Como observa Foucault (2008), as formações discursivas são constituídas a partir das relações entre enunciados, funções enunciativas e regras, orientadas por regularidade específica. Desta forma, através da correspondência entre os três níveis citados, foi possível desvelar uma formação discursiva, denominada Pretensa objetividade e imparcialidade da imprensa.

A definição da referida formação relaciona-se ao argumento, por parte do agente discursivo estudado, de que os dados e informações por ele divulgados, apresentar-se-iam de forma objetiva e imparcial, delimitados por fatos inquestionáveis, apelando à racionalidade dos leitores. É possível observar, entretanto, por meio das regras, funções enunciativas e enunciados revelados que tal objetividade e imparcialidade não se constituem na prática discursiva do agente, ou pelo menos não como única.

Desta forma, seja posicionando-se favoravelmente às decisões dos governantes ou denunciando a ineficiência na execução das ações pelo governo e criticando os obstáculos impostos pelo próprio Estado, quanto aos projetos associados ao PROMOB, não se pode afirmar que a formação discursiva deste agente se apresenta isenta de qualquer posicionamento ou orientação 
ideológica. A Figura 3, apresentada abaixo, indica o mapa de relações indicado anteriormente.

Figura 3 - Mapa de relações

Enunciados

\begin{tabular}{|c|}
\hline $\begin{array}{l}\text { As ações do PROMOB propiciarão melhores } \\
\text { condições de vida para a população. }\end{array}$ \\
\hline $\begin{array}{c}\text { As ações do PROMOB realizarão grande } \\
\text { investimento de dinheiro público em diversos } \\
\text { projetos. }\end{array}$ \\
\hline $\begin{array}{c}\text { Somente os atuais governantes apresentam } \\
\text { real interesse em concretizar as ações do } \\
\text { PROMOB, mesmo aquelas previstas há } \\
\text { muitos anos. }\end{array}$ \\
\hline $\begin{array}{l}\text { As ações do PROMOB propagam } \\
\text { investimento público outros meio de } \\
\text { transporte, diferentes do automóvel. }\end{array}$ \\
\hline $\begin{array}{c}\text { O excesso de burocracia atrapalha a execução } \\
\text { dos projetos planejados. }\end{array}$ \\
\hline $\begin{array}{l}\text { A intromissão de outros órgãos do Estado } \\
\text { atrapalha a execução dos projetos planejados. }\end{array}$ \\
\hline $\begin{array}{l}\text { A ineficiência atrapalha a execução dos } \\
\text { projetos planejados. }\end{array}$ \\
\hline $\begin{array}{c}\text { Apesar das promessas dos atuais governantes, } \\
\text { existem dúvidas sobre a real implementação } \\
\text { dos projetos do PROMOB. }\end{array}$ \\
\hline $\begin{array}{l}\text { A segurança e o cuidado à população não é } \\
\text { prioridade na execução dos projetos do } \\
\text { PROMOB. }\end{array}$ \\
\hline
\end{tabular}

Fonte: Elaborado pelos autores, 2015.

Através do processo interpretativo da produção comunicativa, destaca-se que tal formação discursiva parece profundamente alinhada ao modelo apresentado por Hall (2003). Assim, o processo comunicativo apresenta-se alinhado a ideologia hegemônica, fortalecendo características de dominação, a partir da codificação de determinados signos identificáveis por indivíduos de uma sociedade, em específico tempo histórico. Mais precisamente quanto ao exercício de uma força dominante, observa-se a identificação de uma formação discursiva (Escosteguy, 2007; Franco \& Leão, 2013) que coaduna com o fortalecimento do meio pelo qual a notícia é veiculada, por meio de um processo que também escolhe o que vai ser veiculado e como o será. Em outras palavras, destaca-se que, independentemente da recodificação da comunicação realizada pela audiência, esta apresentar-se-ia limitada, "operando dentro do código dominante" (Hall, 2003, p.400).

Com base nas análises realizadas e apresentadas neste tópico foi possível inferir considerações a respeito do campo discursivo estudado objetivando responder à pergunta de pesquisa formulada inicialmente. Tais questões serão detalhadas na sessão seguinte.

\section{Considerações finais}

Conforme observado, a mobilidade apresenta-se como uma das questões críticas relativas ao cenário urbano brasileiro, decorrente de um modelo de urbanização rápido, desordenado e concentrado em poucos e agigantados centros urbanos. Tais condições levaram a intensificação de diversos aspectos já
Funções
Enunciativas
Regras
Formação
Discursiva

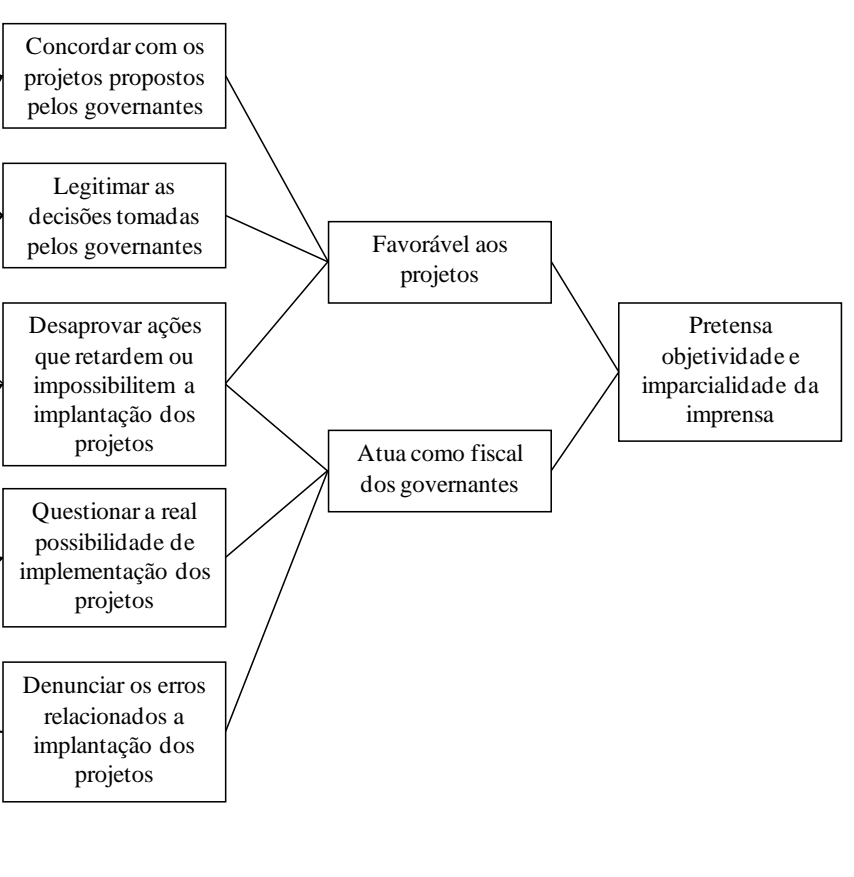

problemáticos destas cidades, e associaram à mobilidade urbana no Brasil também um fator de segregação e restrição de oportunidades e cidadania (Brito \& Souza, 2005; Brito, 2007; Maricato,2003; Maricato, 2013; Zizek, 2013).

Em um cenário tão complexo e desequilibrado poder-se-ia supor que aumenta a responsabilidade do Estado no papel de gestor do espaço urbano. Entretanto, as políticas públicas direcionadas para a questão da mobilidade urbana no Brasil apresentaram prioritariamente viés técnico e econômico, além do fato de habitualmente serem determinadas a partir dos interesses dos grupos sociais hegemônicos, nacionais e internacionais (Aragão et al, 2001; Nunes, 2011; Vasconcellos, 2001). Esta última parece apresentar-se prática ainda recorrente no cenário político-institucional brasileiro (Ribeiro \& Santos, 2007; Maricato, 2013).

Diante de uma realidade tão desigual e, ao mesmo tempo, crucial para a sobrevivência e qualidade de vida de boa parte da população, o Governo do Estado de Pernambuco, ator político responsável pela formulação e implantação de políticas de mobilidade urbana em seu estado, apresentou, em agosto de 2010, o Plano Estadual de Mobilidade Urbana, O PROMOB, considerado por seus autores um marco dentre as políticas de mobilidade já realizadas na região. Tal questão refere-se ao fato de que o direcionamento de tal programa, enfatizado pelos representantes do governo, estaria orientado para a expansão da oferta e melhoria da qualidade do transporte coletivo, além do foco em desenvolver novos modais de transporte, considerados ainda 
alternativos no cenário atual (Governo do Estado de Pernambuco, $\mathrm{s} / \mathrm{d})$.

Apesar do grande furor da imprensa local diante dos projetos apresentados pelo governo, tais argumentos são questionados por Béhar (2014). Tal estudo destaca que as práticas associadas ao planejamento xe execução dos projetos se relacionam profundamente com aspectos já executados no passado e em muito pouco representariam de fato todo este potencial de transformação e melhoria da mobilidade urbana para a RMR. Desta forma, ressalta o papel exercido pela imprensa.

Ao invés de um meio de informação geral, atuando também como fiscalizador das ações dos representantes do Estado e da sociedade, a prática da imprensa brasileira, fortemente concentrada nas mãos de famílias tradicionais e/ou políticos conservadores, parece apresentar-se profundamente associada aos interesses das elites nacionais, escolhendo "o que veicular" e "como comunicar" de forma a não ferir interesses não revelados. Outro aspecto relevante sobre o papel da imprensa é que esta poderia apresentar-se como um agente ativo para contribuição para o debate sobre a reformulação de tais políticas públicas (Souza, 2006; Kucinski, 2011; BBC Brasil, 2011; Stadnik, 1991).

Sobre tais observações, ressalta-se também o destacado modelo de análise de comunicações apresentado por Hall (2003). A partir de uma perspectiva de codificação/decodificação, o autor dá ênfase aos processos subjetivos inerentes à comunicação, orientado pela dimensão ideológica deste compreendendo que o ato de escolher os signos e sentidos para formulação de uma mensagem (codificação) apresenta também em suas nuances dimensões de compreensão que podem ou não ser compreendidas e aceitas pelo receptor da mensagem (decodificação). Neste cenário, o poder da comunicação pode estar não somente na carga ideológica presente na comunicação, mas também (e talvez especialmente) no estabelecimento das referências à compreensão do fenômeno, orientando posicionamentos favoráveis, parciais ou contrários à comunicação realizada (Porto, 2003; Escosteguy, 2007, Oliveira, 2009; Franco \& Leão, 2013).

Desta forma, a partir das informações apresentadas e a fim de orientar as considerações finais a sobre as análises realizadas, faz-se relevante retomar o objetivo principal da pesquisa, a partir da questão norteadora: Como se apresenta o discurso da imprensa pernambucana em relação aos projetos associados

\section{ao PROMOB?}

Recorrendo novamente a Hall (2003), destaca-se que a busca por responder à pergunta de pesquisa orienta-se pelo momento de circulação da comunicação, ainda que esta se apresente como base para interpretação quanto ao momento de produção da mesma pelos agentes discursivos da imprensa local. Sobre este aspecto, a ação interpretativa buscou na análise do discurso foucaultiana as ações para composição de um cenário de produção da comunicação. A respeito de tal prática analítica observa-se que tem na linguagem a ferramenta para construção de um dado conhecimento relativo a específico momento histórico. Neste sentido, observa-se que a proposição do referido estudo se apresenta orientada a revelar as unidades discursivas de um agente, no caso a imprensa, inserido em um dado contexto histórico e social.

Portanto, a formação discursiva (pretensa objetividade e imparcialidade da imprensa) aponta para o objetivo de estabelecer seu campo discursivo a partir de construções objetivas e imparciais, possivelmente com o intuito de ser reconhecido como um ator confiável e referenciado em sua sociedade. Entretanto, a análise da constituição de tal formação leva a conclusão de que o discurso apresentado pela imprensa pernambucana em relação aos projetos do PROMOB estaria direcionado a determinados interesses específicos e muito pouco apresentaria das características apresentadas acima.

Neste caso, o agente discursivo se coloca em favor dos projetos, legitimando e concordando com o mesmo, ao mesmo tempo em que critica e ataca outros atores da sociedade que põem em risco sua implementação.

Desta forma, a regra atua como fiscal do governo demonstraria o posicionamento quase que advocatício do referido agente discursivo diante dos riscos ou barreiras para conclusão dos projetos, dando suporte a outra regra revelada, denominada favorável aos projetos. Esta, por sua vez, é apresentada de forma mais direta e clara pelo agente discursivo.

Apoiando tais observações, cabe destacar que em nenhum dos documentos que compõem o corpus da pesquisa foi identificada qualquer menção a questionamento ou crítica direcionada aos projetos apresentados. Ao contrário, o foco das preocupações, como já observado, relaciona-se somente com a justa, eficiente e rápida instalação das ações propostas. Tal questão relaciona-se aos enunciados: Somente os atuais governantes apresentam real interesse em concretizar as ações do PROMOB, mesmo aquelas previstas há muitos anos, o excesso de burocracia atrapalha a execução dos projetos planejados, a intromissão de outros órgãos do Estado atrapalha a execução dos projetos planejados, a ineficiência atrapalha a execução dos projetos planejados, apesar das promessas dos atuais governantes, existem dúvidas sobre a real implementação dos projetos do $\mathrm{PROMOB}$, a segurança e o cuidado à população não é prioridade na execução dos projetos do PROMOB.

Complementarmente observa-se que, a partir da expectativa de neutralidade, imparcialidade e objetividade na comunicação jornalística (Souza, 2006), a imprensa local se apresentaria, por meio das regras de formação discursiva, como um ator ativo na tentativa de legitimar as ações dos governantes locais, ao mesmo tempo em que buscaria junto a sua audiência legitimar-se como agente de fiscalização dos governantes locais. O que inicialmente poderia ser interpretado como uma contradição parece apresentar seu sentido mais oculto a partir da identificação da formação discursiva. Quanto a esta, a imprensa local reforçaria ainda mais o seu status na sociedade, possivelmente apresentando a perspectiva de "Quarto Poder", destaca por Souza (2006) e Kucinski (2011), através da escolha por informações para veiculação que reforcem (ou busquem legitimar) junto a sua 
audiência sua relevância e distanciamento de possíveis interesses secundários.

Estas compreensões também se relacionam fortemente ao modelo codificação/decodificação, proposto por Hall (2003). Destacando que a interpretação presente neste trabalho se direciona ao momento de produção, a partir do momento de circulação, supõe-se o papel dos veículos de impressa como reprodutores da lógica hegemônica. Sobre tal questão, identificouse que, subjacente às notícias apresentadas, estaria presente a intenção de reafirmação do veículo enquanto isento e confiável, ou, em outras palavras, como reprodutor de uma realidade objetiva e consistente com uma interpretação que é única e consolidada.

A este respeito, cabe ainda destaque a dois aspectos. Primeiramente quanto à utilização do discurso (por meio dos signos socialmente reconhecidos) para comunicação de informações e ideologias que, necessariamente não se vinculam à notícia apresentada. Assim, a análise realizada coaduna com o modelo de Hall (2003) no sentido de que mais do que somente informações sobre determinado fenômeno são comunicadas por meio do discurso, neste caso o discurso jornalístico.

Entretanto, quanto ao momento de distribuição/consumo, é necessário ressaltar a passividade do discurso escrito perante os indivíduos. Neste sentido, observa-se a tendência de que os conteúdos apresentados na comunicação, que objetivamente em nada se relacionam à formação discursiva identificada, apresentam-se como chamariz para despertar o interesse destes indivíduos, transformando-os em audiência.

Por fim, destaca-se que a decodificação e compreensão da comunicação codificada e enviada está aquém do controle do codificador. Assim, o discurso apresentado pela imprensa poderia ter sua influência reduzida ou mesmo impacto diverso ao que se havia desejado no momento de produção. Há de se destacar, contudo, que o próprio modelo de Hall (2003) prevê tal circunstância, observando que, mesmo não se apresentando efetivo em seu objetivo comunicacional, tal mensagem (inserida no discurso) apresentar-se-ia como código hegemônico dominante, que limitaria e direcionaria a compreensão da audiência.

Sobre tais considerações, destaca-se que este estudo apresenta como limitações a utilização unicamente de documentos que, apesar de contribuírem para compreensão dos fenômenos, também possuem suas limitações quanto a profundidade e amplitude de análise, além do período limitado da pesquisa e mesmo do estágio inacabado de praticamente todas as obras associadas ao PROMOB. Compreende-se, desta forma, a necessidade de realização de novos estudos que possibilitem não somente aprofundar a compreensão quanto ao discurso da imprensa, inclusive quanto a outros temas, mas também, e principalmente, busquem compreender de que forma estes discursos são decodificados pela audiência.

\section{Referências}

ARAGÃO, J. J. G.; BRASILEIRO, O. L. N. A.; SANTOS, E. M.; SENNA, J. M.; FILHO, R.D. O (nov. 2011). Transportes no Brasil: que história contar. TRANSPORTES, vol.9, no 2 2, pp. 87-107.
BBC BRASIL (jul/2011). Conheça os principais magnatas da mídia no mundo. Disponível em: http://www.bbc.co.uk/portuguese/noticias/2011/07/110718 magnatas bg_cc .shtml . Acesso em: 18 jan 2015.

BÉHAR, Alexandre H. (2014). O desenvolvimento e as políticas públicas de mobilidade urbana: uma análise do Programa Estadual de Mobilidade Urbana do Governo do Estado de Pernambuco (PROMOB). Dissertação de Mestrado - Universidade Federal de Pernambuco.

BRITO, Fausto (2007). Urbanização, Metropolização e Mobilidade Espacial da População: um breve ensaio além dos números. Taller Nacional sobre "Migración interna y desarollo em Brasil: diagnóstico, perspectivas y políticas, Brasília, DF, Brasil.

; SOUZA, Joseane de (out. /dez, 2005). Expansão urbana nas grandes metrópoles: o significado das migrações intrametropolitanas e da mobilidade pendular na reprodução da pobreza. São Paulo em Perspectiva, vol. $19, n^{\circ} 4$, p. $48-63$.

COMPANHIA BRASILEIRA DE TRENS URBANOS - CBTU (s/d). Disponível em: http://www.cbtu.gov.br/sistemas/rec/veja/regmetroporec_cont.htm. Acesso em 28 fev 2014.

COSTA, A. de Sá M.; VERGARA, S. C. (jan/abr 2012). Estruturalista, pósestruturalista ou pós-moderno? Apropriações do pensamento de Michel Foucault por pesquisadores da área de Administração no Brasil. Gestão e Sociedade, vol. 16, no 13, p 69-89.

DANTAS, J. G. D. (2008). Teoria das Mediações Culturais: Uma Proposta de Jesús Martín-Barbero para o Estudo de Recepção. In: X Congresso de Ciências da Comunicação na Região Nordeste, São Luís, MA.

DIÁRIOS ASSOCIADOS (s/d). Diário de Pernambuco. Disponível em: http://www.diariosassociados.com.br/home/veiculos.php?co_veiculo=33

Acessado em: 15 dez 2015.

ESCOSTEGUY, A. C. (2007). Circuitos de cultura/circuitos de comunicação: um protocolo analítico de integração da produção e da recepção. Comunicação, Mídia e Consumo. São Paulo, v.4, n.11, p.115-315, nov.

FLICK, Uwe (2009). Introdução à Metodologia de Pesquisa: um guia para iniciantes. Porto Alegre: Penso.

FOLHAPE (s/d). Quem somos. Disponível em: http://www.folhape.com.br/institucional/quemSomos/index.html . Acesso em: 15 dez 2015.

FOUCAULT, Michel (2008). A arqueologia do saber. Rio de Janeiro: Forenses.

FRANCO, S.M.; LEÃO, A. L. M. de S. (2013). Codificando/decodificando a comunicação organizacional: uma contribuição dos estudos culturais. Revista Pensamento Contemporâneo em Administração. Rio de Janeiro. V.7, n.1, jan/mar.

GOVERNO DO ESTADO DE PERNAMBUCO (s/d). PROMOB, Programa de Mobilidade

Urbana. Disponível em: http://www.pe.gov.br/programas/promob-programademobilidade-urbana/. Acesso em: 5 fev 2014.

(2011). Comitê Popular da Copa PE participa de audiência pública sobre transporte e mobilidade urbana. Disponível em: http://comitepopularpe.files.wordpress.com/2011/08/apresentac3a7c3a3omodo-decompatibilidade.pdf . Acesso em 12 de jan de 2014.

(2012). Programa Estadual de Mobilidade Urbana - PROMOB. Disponível
http://www.ntu.org.br/novosite/arquivos/2012/Cristina_Aroucha_2\%C2\%AAp arte.pdf.

Acesso em 6 mar 2014.

GRANDE RECIFE CONSÓRCIO DE TRANSPORTES (s/d). EMTU Histórico. Disponível em: http://www.granderecife.pe.gov.br/granderecife_historico_link.asp. Acesso em 05/03/2014.

GUAZINA, Liziane (jul-dez 2007). O conceito de mídia na comunicação e na ciência política: desafios interdisciplinares. Revista Debates, v.1, n.1, p. 4964.

HALL, Stuart. Codificação/Decodificação (2003). In: HALL, S. Da Diáspora: identidades e mediações culturais. Belo Horizonte: Editora UFMG.

JCPM (s/d). História. Disponível em: http://www.jcpm.com.br/historialnterna.php?id_pai=1. Acesso em: $15 \mathrm{dez}$ 2015.

JORNAL DO COMMÉRCIO (2015). Sobre o Jornal do Commércio. Disponível em: http://comercialjc.jconline.ne10.uol.com.br/ . Acesso em: 15 dez 2015.

(s/d). Por dentro do JC. Disponível em: http://www.assinejc.com.br/FiquePorDentroJC.aspx . Acesso em $15 \mathrm{dez}$ 2015.

(ago/2011). Trânsito do futuro no Recife. Disponível em: http://pedesenvolvimento.com/2011/08/11/transito-do-futuro-no-recife/. Acesso em 5 mar 2014.

KUCINSKI, B (mar/2011). O poder da imprensa e os abusos do poder. Observatório de Imprensa, edição no 634 . Disponível em: http://www.observatoriodaimprensa.com.br/news/view/o-poder-da-imprensae-os-abusos-do-poder . Acesso em 18 jan 2015. 
MARICATO, Ermínia (2003). Metrópole, legislação e desigualdade. Estudos Avançados, vol. 17, no 48, p. 151-167. vol.37, p.5-12. (jul/dez. 2008). O automóvel e a cidade. Ciência\&Ambiente, (2013). É a questão urbana, estúpido! In MARICATO, Ermínia et al. Cidades rebeldes: Passe Livre e as manifestações que tomaram as ruas do Brasil. São Paulo: Boitempo: Carta Maior, 2013.

MARIZ, Luiz A.; GOULART, Sueli; RÉGIS, Helder P.; DOURADO, Débora (jul/2005). O reinado dos estudos de caso na teoria das organizações: imprecisões e alternativas. Cadernos EBAPE, volume III, número 3, pp. 1 14.

MARTín-BARBERO, J. (2003). Pistas para entre-ver meios e mediações. Dos meios às mediações - Comunicação, cultura e hegemonia. Rio de Janeiro: Editora UFRJ.

NASCIMENTO, Tatiana (2013). Caminho sem volta. PERNAMBUCO.COM. Disponível

http://blogs.diariodepernambuco.com.br/economia/?p=14887. Acesso em: 6 mar 2013.

NUNES, Ivanil (2011). Acumulação de capitais e sistemas de transporte terrestres no Brasil. In FILHO, Alcide G. e QUEIROZ, P. R. C. Transportes e formação regional: contribuições à história dos transportes no Brasil. Dourados: Ed. UFGD.

OBSERVATÓRIO DAS METRÓPOLES (2006). Universidade Federal de Pernambuco (UFPE). Como anda a Região Metropolitana do Recife. Recife, Pernambuco.

OLIVEIRA, V. C (2009). Novo Sentido da Comunicação Organizacional: construção de um espaço estratégico. XXVI Congresso Brasileiro de Ciências da Comunicação. Belo Horizonte.

PAIVA, F. G. de P. J.; LEÃO, A. L. M. de S.; MELLO, S. C. B. de (set/dez 2011). Validade e confiabilidade na pesquisa qualitativa em Administração. Revista de Ciências da Administração. v. 13, n. 31, p. 190-209.

PAULA, A. P. P. de (2008). Teoria crítica nas organizações. São Paulo: Thompson Learning.

PESCHANSKI, João Alexandre (2013). O transporte público gratuito, uma utopia real. In Ermínia Maricato et al. Cidades rebeldes: Passe Livre e as manifestações que tomaram as ruas do Brasil. São Paulo: Boitempo: Carta Maior.

PORTO, M. P (2003). A pesquisa sobre a recepção e os efeitos da mídia: propondo um enfoque integrado. XXVI Congresso Brasileiro de Ciências da Comunicação. Belo Horizonte.
PREFEITURA DO CIDADE DO RECIFE (jun/2011). Plano de Mobilidade do Recife - Diretor de Transporte e Mobilidade Urbana. Disponível em http://www2.recife.pe.gov.br/projetos-e-acoes/projetos/plano-diretor-detransporte-e-mobilidade-urbana-2/. Acesso em: 6 mar 2014.

REDE BRASIL NOTÍCIAS (jun/2014). Recife é a capital mais "engarrafada" do Brasil. Disponível em: http://noticias.rbc1.com.br/cidades/28197/recife-ea-capital-mais-\%27engarrafada-do-brasil.html . Acesso em 18 jan 2015

RIBEIRO, Luiz C. de Q.; SANTOS, Orlando A. dos, Júnior (2007). As Metrópoles brasileiras: Territórios desgovernados. In: Luiz C. de Q. Ribeiro e Orlando A. dos Santos Júnior (Org.). As Metrópoles e a questão social brasileira. Rio de Janeiro, Editora Revan, Fase.

RODRIGUES, F (abr/2014). Dilma gasta R\$ 2,3 bi com publicidade em 2013 $e$ bate recorde. Folha de S.Paulo, Poder. Disponível em: http://www1 .folha.uol.com.br/poder/2014/04/1441349-dilma-bate-recordeem-gastos-publicitarios.shtml . Acesso em 18 jan 2015.

RONSINI, V. V. M. (2010). A perspectiva das mediações de Jesús MartínBarbero (ou como sujar as mãos na cozinha da pesquisa empírica de recepção). In: XIX Encontro da Compós, Rio de Janeiro, RJ.

SECRETARIA DAS CIDADES (2011). Programa Estadual de Mobilidade Urbana. Recife,

Governo do estado de Pernambuco.

SOUZA, J. P (2006). Elementos de Teoria e Pesquisa da Comunicação e dos Media. Porto: Porto.

STADNIK, Célia (1991). A hipótese do fenômeno do "coronelismo eletrônico" e as ligações dos parlamentares federais e governadores com os meios de comunicação de massa no Brasil. [monografia] Curso de Jornalismo. Porto Alegre: Faculdade dos Meios de Comunicação Social, PUC/RS.

VAINSENCHER, Semira Adler (s/d). Metrô do Recife (Metrorec). Pesquisa Escolar Online, Fundação Joaquim Nabuco, Recife. Disponível em: <http://basilio.fundaj.gov.br/pesquisaescolar/>. Acesso em:6 mar 2014.

VASCONCELLOS, Eduardo A (2001). Transporte urbano, espaço e equidade: análise das políticas públicas. São Paulo: Annablume.

WOTRICH, Laura, SILVA, Renata C. da; RONSINI, Veneza M. (2009) A perspectiva das mediações de Jesús Martín-Barbero no estudo de recepção da telenovela. In: XXXII Congresso Brasileiro de Ciências da Comunicação, Curitiba, PR

ZIZEK, Slavoj (2013). Problemas no Paraíso. In Ermínia Maricato et al. Cidades rebeldes: Passe Livre e as manifestações que tomaram as ruas do Brasil. São Paulo: Boitempo: Carta Maior. 